\title{
Physiological Functions and Pathology of Ghrelin
}

\author{
Takahiro Sato ${ }^{1, ~ *}$, Kanae Oishi ${ }^{1}$, Takanori Ida $^{2}$, Masayasu Kojima ${ }^{1, ~ * ~}$ \\ ${ }^{1}$ Molecular Genetics, Institute of Life Science, Kurume University, Kurume, Japan \\ ${ }^{2}$ Division for Searching and Identification o Bioactive Peptides, Department of Bioactive Peptides, Frontier Science Research Center, \\ University of Miyazaki, Miyazaki, Japan
}

\section{Email address:}

satou_takahiro@kurume-u.ac.jp (T. Sato), kojima_masayasu@kurume-u.ac.jp (K. Masayasu)

\section{To cite this article:}

Takahiro Sato, Kanae Oishi, Takanori Ida, Masayasu Kojima. Physiological Functions and Pathology of Ghrelin. American Journal of Life Sciences. Special Issue: Biology and Medicine of Peptide and Steroid Hormones. Vol. 3, No. 3-2, 2015, pp. 8-16.

doi: $10.11648 /$ j.ajls.s.2015030302.13

\begin{abstract}
Ghrelin is a peptide hormone made up of 28 amino acid residues; the N-terminal serine 3 residues is modified by octanoic acid, a medium-chain fatty acid. Ghrelin is mainly secreted by the stomach and has various effects, including growth hormone release, hyperphagia, lipid accumulation, suppression of insulin secretion, and hypotensive effects. Most of these physiological effects are indispensable functions for the maintenance of homeostasis and contribute to the onset and promotion of metabolic syndrome. Accordingly, it is important to combine etiological and pathological understanding based on the biochemistry and physiology of ghrelin, which has a characteristic structure. In this manuscript, after presenting biochemical information on ghrelin, we provide an outline of its physiological function.
\end{abstract}

Keywords: Ghrelin, Ghrelin-O-Acyltransferase, Appetite

\section{Introduction}

G-protein coupled receptors (GPCRs), which are an important target of innovative drug development, are widely involved in biological phenomena such as intercellular signal transmission and cell proliferation and differentiation, and GPCRs also act as receptors for various ligands, ranging from ions to proteins. GPCRs are seven transmembrane receptors and comprise a small proportion of the entire human genome, forming the fourth largest protein family. Of the GPCRs, those with unknown ligands are known as orphan GPCRs. There are said to be approximately 300 types of orphan GPCRs, and their intrinsic ligands have facilitated the elucidation of novel biological information systems and paved the way for innovative drug development. Therefore, they have been proactively investigated mainly during the 1990s.

Meanwhile, in 1976, a report was written concerning weak growth hormone $(\mathrm{GH})$ secretory activity that was mediated by a receptor and not by growth hormone releasing hormone (GHRH) (1). The GHRH signal is mediated by cyclic AMP, while the second messenger for this receptor is calcium (Fig. 1). Thereafter, the primary structure of this receptor was revealed through expression cloning in 1996, and it came to be known as growth hormone secretagogue receptor (GHS-R) (2). This receptor was a typical GPCR; therefore, a search for the intrinsic ligand of GHSR, whose existence was called into question, was performed on a global level. Most researchers focused their search on the brain because GHS-R is widely distributed in the central nervous system (2-4), but their endeavors were not fruitful. However, advances made during the investigation of the stomach of rats and humans by Kojima and Kangawa et al. (1999) led to the identification of ghrelin (GHRL), the intrinsic peptide that activates GHS-R (5).

In this review, we will review the biochemical and physiological knowledge of ghrelin.

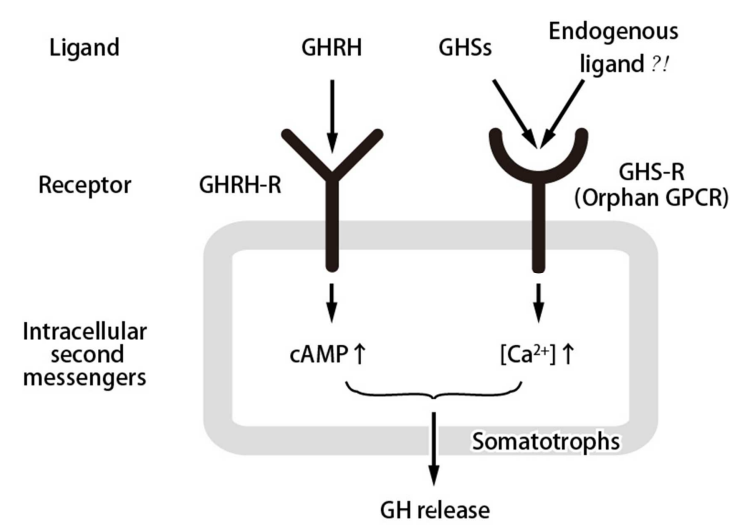

Figure 1. Second messenger systems of GHRH and GHSs (based on Kojima et al. 2005 [6]). 


\section{Biochemistry of Ghrelin and Related Substances}

\subsection{Ghrelin}

The human ghrelin gene is present on the third chromosome at 3p25-26 (7). It is made up of six exons; ghrelin, which is made up of 28 amino acids (Fig. 2), is coded by the second and third exon $(8,9)$. In the ghrelin molecule, N-terminal serine 3 residues is characteristically bound via esterification to octanoic acid, a fatty acid, at carbon number 8 (Fig. 3) (5). However, bioactive peptides other than ghrelin that undergo this type of fatty acid modification have not been found in vertebrate. The amino acid sequence of ghrelin precursors has been extremely well preserved in mammals, and ghrelin has also been identified in various other species, including birds, fish, and amphibians; in all species, a fatty acid is appended to the serine 3 or threonine 3 residue $(6,9-18)$. The molecular weight of human ghrelin is $3370.9 \mathrm{kDa}$.

Ghrelin molecules without appended fatty acids are known as desacyl ghrelin (hereafter, "ghrelin" will refer to ghrelin that has been modified by octanoic acid). Although there are reports stating that desacyl ghrelin has an appetite-suppressing effect on the central nervous system (19), this mechanism may not be mediated by GPCR because desacyl ghrelin does not bind to GHS-R. We believe that further studies are required to clarify this issue.

Human: MPSPGTVCSLLLLGMLWLDLAMAGSSFLSPEHQRVQQRKESKKPPAKLQP

Rat: MVSSATICSLLLLSMLWMDMAMAGSSFLSPEHQKAQQRKESKKPPAKLQP

Mouse: MLSSGTICSLLLLSMLWMDMAMAGSSFLSPEHQKAQQRKESKKPPAKLQP signal peptides ghrelin

51

Human: RALAGWLRPEDGGQAEGAEDELEVRFNAPFDVGIKLSGVQYQQHSQALGK

Rat: RALEGWLHPEDRGQAEEAEEELEIRFNAPFDVGIKLSGAQYQQHGRALGK

Mouse: RALEGWLHPEDRGQAEETEEELEIRFNAPFDVGIKLSGAQYQQHGRALGK the $\mathrm{COOH}$ terminus of the ghrelin peptides

\begin{tabular}{ll}
\multicolumn{1}{c}{101} & 117 \\
Human: & FLQDILWEEAKEAPADK \\
Rat: & FLQDILWEEVKEAPANK \\
Mouse: & FLQDILWEEVKEAPADK
\end{tabular}

Figure 2. Amino acid sequences of ghrelin (based on Kojima et al. 2005 [6])

\subsection{Ghrelin-O-Acyltransferase}

Because fatty acid modification is essential during the expression of ghrelin activity, a proactive search was made for enzymes that appended fatty acids, and in 2008, ghrelin- $O$-acyltransferase (GOAT) was identified (20). The discovery of this enzyme triggered the discovery of an acyltransferase known as porcupine. Porcupine is an enzyme that performs fatty acid modification of Wnt, which is related to embryogenesis and cancer. When this discovery was made, a protein from a database with structural characteristics of the membrane-bound $O$-acyltransferase family was analyzed. Yang et al. restricted the search to 16 candidate molecules; of these, GOAT was discovered to be the enzyme that bound $n$-octanoic acid on ghrelin. Localization of this enzyme was extremely consistent with the cells that secrete ghrelin. In addition, the optimal temperature for this enzyme reaction was reported to be $37-50{ }^{\circ} \mathrm{C}$, with an optimal $\mathrm{pH}$ value of $7-$ $8(21)$.
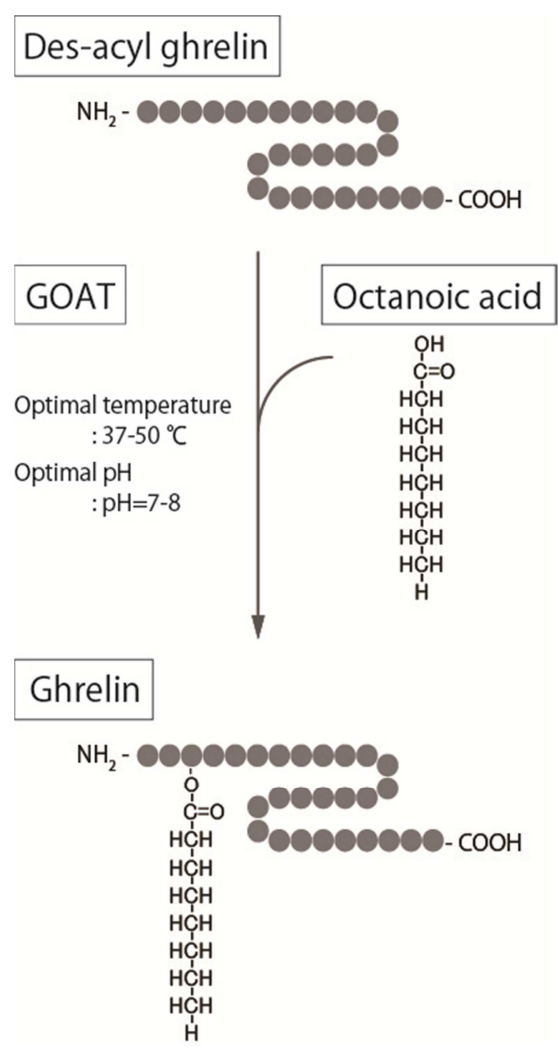

Figure 3. Activation process of ghrelin (based on Kojima et al. 2005 [6]).

\subsection{Ghrelin Receptor}

The human ghrelin receptor gene is present at the $3 q 26-27$ on the third chromosome (7), the same chromosome with ghrelin. The human ghrelin receptor gene is made up of two exons; the first to fifth transmembrane domains are present in the first exon, and the sixth to seventh transmembrane domains are present in the second exon. Through alternative splicing, two mRNA molecules, GHS-R1a and GHS-R1b, can be produced from the ghrelin receptor gene (2). Of these, GHS-R1a functions as a GPCR with seven transmembrane domains and ghrelin receptor. On the other hand, the inactive variant of GHS-R, GHS-R1b, appears to play a critical role in modulating the activity of GHS-R1a by forming heterodimeric complexes which attenuates trafficking of the active variant to the cell surface (22). The ghrelin receptor has $52 \%$ homology with the amino acid sequence of the motilin receptor, a peptide that promotes gastrointestinal motility (23-25). The ghrelin receptor is coupled to a trimeric $\mathrm{Gq}$ protein and promotes release of $\mathrm{Ca}^{2+}$ from endoplasmic reticulum through production of inositol-3-phosphate and phospholipase activation, leading to ghrelin signal transmission. Ghrelin receptors are expressed in many tissues throughout the body, and as mentioned later, ghrelin control various physiological functions. 


\subsection{Obestatin}

Obestatin is a peptide made up of 23 amino acid residues that was isolated from the stomach of rats (26). Reports indicate that despite being produced by cleavage from a ghrelin precursor, it demonstrates physiological effects opposite to those of ghrelin, acting as an appetite suppressant. From the results of immunohistochemical staining in rats, obestatin is reported to be present in the mucosal cells of the stomach, nerve plexuses in the gastrointestinal system, and the Leydig cells in the testes. In addition, almost all obestatin-immunopositive neurons in gastrointestinal nerve plexuses are said to co-exist with choline acetyltransferase. When obestatin was initially discovered, it gained attention as a novel appetite suppressant peptide; however, reproducibility could not be confirmed in experiments performed by various groups (27-29). Holst et al. reported that GPR39 signaling is stimulated by zinc ions but not by obestatin (28). Moreover, Nogueiras et al. failed to find any effect of obestatin on GH secretion in vivo, and they also unable to find mRNA expression of GPR39, the putative obestatin receptor, in the hypothalamus of rats (30). For this reason, use of commercially available obestatin EIA kits should be carefully monitored.

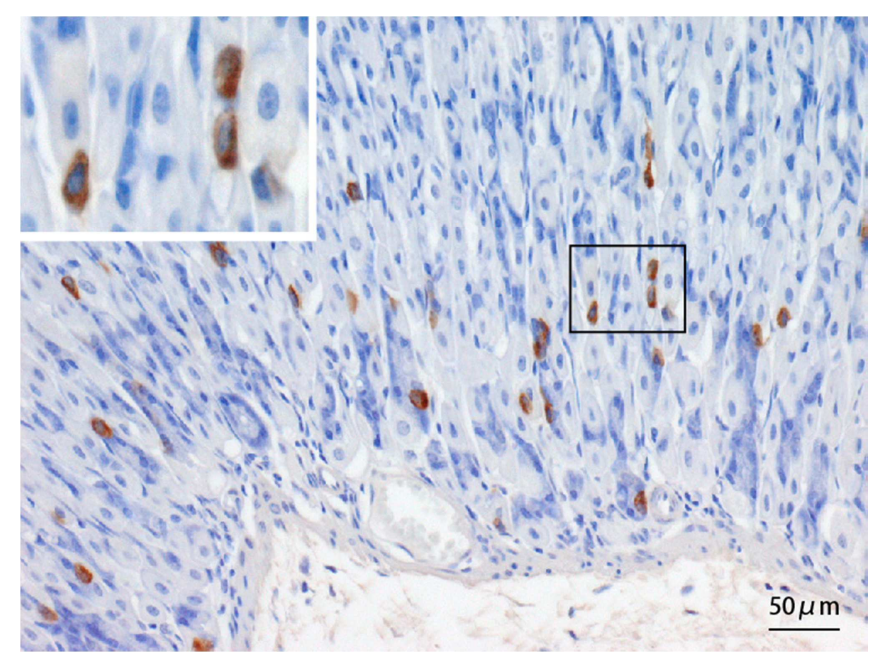

Figure 4. Distribution of ghrelin-immunopositive cells in the mucosa of the stomach. Insert photo expansion of the black frame region.

\section{Distribution of Ghrelin and Regulation of Ghrelin Secretion}

\subsection{Histological Distribution of Ghrelin}

The principal site of ghrelin production is the stomach (Fig. 4), particularly the fundic gland, where there are several secretory glands. This is the same for mammals and all non-mammalian species. In ruminants such as bovine and sheep that have multiple stomachs, ghrelin is produced in the glandular stomach. The gastric ghrelin cells are closed endocrine cells that are not in contact with the gastric lumen, have a roughly uniform size (diameter, $120 \mathrm{~nm}$ ), and contain several highly electro-dense secretory granules (31). In rats, approximately $2 \%$ of the gastric mucosa is made up of endocrine cells, and of these, approximately $20-25 \%$ are ghrelin cells. These are the second most common cells after enterochromaffin-like (ECL) cells that secrete histamine.

In addition, ghrelin is also present in the duodenum, small intestine, pancreas, hypothalamus, placenta, and kidneys, although with extremely low concentrations. In the central nervous system, ghrelin-producing neurons are present in the lateral arcuate nucleus, and the nerve fibers project into other nuclei such as the median eminence and the hypothalamus (6, 32).

\subsection{Plasma Concentration of Ghrelin}

Ghrelin secreted by the stomach circulates in the blood stream as a hormone and acts on target tissues. Plasma ghrelin concentration in humans is $10-20 \mathrm{fmol} / \mathrm{mL}$, and the total concentration of ghrelin and desacyl ghrelin is 100-150 $\mathrm{fmol} / \mathrm{mL}$ (33-35). In rats, ghrelin concentration in the stomach is $377.3 \pm 55.8 \mathrm{fmol} / \mathrm{mg}$ for $n$-octanoyl ghrelin and $1,779.8 \pm$ $533.9 \mathrm{fmol} / \mathrm{mg}$ for total ghrelin (36). Thus, ghrelin concentration is approximately $10-25 \%$ that of desacyl ghrelin concentration.

\subsection{Regulation of Ghrelin}

Secretion of ghrelin is accelerated in low energy states, but the regulatory mechanism remains unknown. Even when the stomach is dilated through the intake of water, there are no changes in the plasma concentration; this demonstrates that stretching stimuli in the stomach does not change ghrelin secretion $(37,38)$. On the other hand, plasma ghrelin concentration is decreased by glucose administration; it increases during fasting and decreases when food is ingested (39). Therefore, plasma glucose concentration is thought to be important for the regulation of ghrelin secretion. Furthermore, in order for ghrelin to have physiological activity, fatty acid modification by GOAT is essential; therefore attention must be paid to GOAT dynamics as well as the secretion process of synthesis, storage, and release.

\section{Physiological Functions and Pathology of Ghrelin}

Metabolic syndrome is initiated by the accumulation of visceral fat due to excess energy intake. Energy metabolism is suppressed by intake and regulation of glycolipid metabolism, and ghrelin is involved in all of these processes. We have now mentioned the main physiological functions of ghrelin (Table 1) and will go on to discuss some of its relationships with pathological conditions.

\subsection{Promotion of GH Secretion}

Both in vitro and in vivo, ghrelin demonstrates powerful GH releasing effect $(5,38-45)$. When ghrelin was administered intravenously to healthy individuals, maximum $\mathrm{GH}$ release occurred after 15-20 min, and increases in the plasma $\mathrm{GH}$ 
levels were maintained for more than $60 \mathrm{~min}$ (42). Furthermore, doses of ghrelin that would not stimulate GH secretion when administered alone caused very powerful GH release stimulating effects when administered with GHRH (41, 45). This shows that, in addition to being independently induced by $\mathrm{GH}$ secretion from $\mathrm{GH}$ cells, $\mathrm{GH}$ secretion is also stimulated by synergistic effects with GHRH. Ghrelin also stimulates the secretion of prolactin (PRL) when administered at high concentrations. Because GHS-R mRNA is expressed in the somatotrophs, mammosomatotrophs that contain both GH and PRL in the same cells, and mammotrophs of the human pituitary adenomas (46), we believe that GH and PRL are also released from mammosomatotrophs as a response to ghrelin stimulation.

Table 1. Physiological functions of ghrelin

\begin{tabular}{lll}
\hline Physiological functions & & Species \\
\hline Growth hormone secretion & $\uparrow$ & human, rats \\
Appetite regulations & $\uparrow$ & human, rats \\
$\quad$ Food intake & $\uparrow$ & rats \\
$\quad$ AMPK activity & & \\
Autonomic nervous system & $\downarrow$ & human, rats \\
$\quad$ Sympathetic nerve activity & $\uparrow$ & \\
Glucose metabolisms & $\uparrow$ & human \\
$\quad$ Blood glucose & $\downarrow$ & human \\
$\quad$ Insulin & & \\
Lipid metabolism & $\uparrow$ & rats \\
$\quad$ Adiposity & $\uparrow$ & rats \\
$\quad$ Triglyceride & $\uparrow$ & \\
Cardiovascular functions & & human, rats \\
$\quad$ Blood pressure & $\downarrow$ & rats \\
$\quad$ Cardiac output & Vasodilation & rats \\
Gastric functions & $\uparrow$ & \\
Gastric acid secretion & $\uparrow$ & rats \\
Gastric movement & & rats \\
\hline
\end{tabular}

$\uparrow$, Stimulate; $\downarrow$, decrease.

In this manner, the main function of ghrelin on GH cell function is to promote the release of $\mathrm{GH}$, and we postulate that ghrelin may be involved in the GH gene expression and the development and differentiation of GH cells. In fact, it is reported that ghrelin, in addition to its GH-releasing activities, is also capable of regulating pit-1 transcription through the GH secretagogue receptor in the pituitary, suggesting the physiological roles of ghrelin on somatotroph cell differentiation and function (47).

\subsection{Actions on Dietary Regulation}

When ghrelin was administered centrally or peripherally in mice and rats, it causes hyperphagia and an increase in body weight (48-53). Hyperphagia caused by ghrelin is not related to the effects that promote GH secretion. Although orexigenic peptides such as neuropeptide Y (NPY) and agouti-related protein $(\mathrm{AgRP})$ are only effective when they are centrally administered, ghrelin can also promote appetite through not only intracerebroventricular administration but also intravenous or intraperitoneal administration; it regulates eating solely as a peripheral hunger signal. The hypothalamus is pivotally involved in the regulation of food intake, and a large amount of information is integrated to suppress energy metabolism. Ghrelin that is administered intraventricularly activates NPY/AgRP neurons with ghrelin receptors and promotes the production and secretion of both peptides, thus causing an appetite-promoting effect (48). In addition, when ghrelin is administered intravenously, it also activates NPY/AgRP neurons and promotes food intake. The latter is dependent on the gastric vagal nerve, a cranial nerve that transmits information from the gastrointestinal system via the brainstem to the diencephalon and neocortex. Ghrelin receptors are produced in the afferent neurons of the vagus nerve and are transported to the terminal end of the afferent fibers; here, ghrelin binds to the receptor and suppresses the electrical activity of the afferent fibers of the vagus nerve (53). This information is transmitted to the medulla oblongata; thereafter, the signals switch neurons and are transported to the NPY/AgRP and GHRH neurons, producing appetite promoting effects and stimulating GH secretion (53). Leptin, which is secreted by adipocytes, suppresses NPY/AgRP neurons, and produces an appetite-suppressing effect, making it an antagonistic to ghrelin (54).

In rats, ghrelin is also secreted small amounts from the hypothalamus (32). Because chronic overproduction of ghrelin in the hypothalamus leads to temporal increase in food intake and body weight (55), ghrelin secreted from the hypothalamus also might have anabolic effects.

Plasma ghrelin concentration showed a negative correlation to body mass index (BMI). It is low in obese individuals and high in lean individuals. However, plasma concentrations in Pima Indians, who readily become obese, are low, and plasma concentrations in patients with anorexia nervosa are high. In addition, plasma ghrelin concentrations are also high in patients with severe cardiac failure or marked cachexia due to lung cancer. In Prader-Willi syndrome, which is caused by a genetic abnormality on chromosome 15 , patients exhibit hyperphagia, and plasma ghrelin concentrations are also high (56). On the other hand, long-acting octreotide treatment causes a sustained decrease in ghrelin concentrations but does not affect weight, behaviour and appetite in subjects with Prader-Willi syndrome (57). The underlying mechanism for these remains unknown, but is extremely interesting.

Recently, Steculorum et al. reported that neonatal ghrelin programs development of hypothalamic feeding circuits (58). Direct exposure of postnatal hypothalamic neuronal explants to ghrelin blunted axonal growth and blocked the neurotrophic effect of the adipocyte-derived hormone leptin. Moreover, chronic ghrelin exposure in neonatal mice also attenuated leptin-induced STAT3 signaling in hypothalamic neurons. Thus, ghrelin regulates not only the food intake after birth, also functions to configure the neuronal network required for food intake regulation. 


\subsection{Effects on Glycolipid Metabolism}

There are many reports on the regulation of insulin secretion by ghrelin (59-61). In a similar manner to insulin, it is also present at higher levels in the pancreatic arteries than in the pancreatic veins. Ghrelin is present in the $\alpha$ cells in the islets of Langerhans that produce glucagon, and the ghrelin receptor gene is expressed in both $\alpha$ and $\beta$ cells. At physiological concentrations of ghrelin $\left(10^{-12}-10^{-11} \mathrm{M}\right)$, there is an increased intracellular $\mathrm{Ca}^{2+}$ concentration during hyperglycemia in pancreatic $\beta$ cells isolated from rats, and insulin secretion is promoted. Meanwhile, during hypoglycemia, ghrelin does not change the free $\mathrm{Ca}^{2+}$ concentration and insulin secretion within $\beta$ cells. In addition, from analysis of the pancreas of mice deficient in the ghrelin gene, it was demonstrated that glucose-induced insulin secretion from pancreatic islet cells is promoted by ghrelin deficiency (62).

While the effect of ghrelin on glucose metabolism is becoming clear, there is also cautious opinion on effect on ghrelin of glucose metabolism. Kirchner et al. ablated GOAT in leptin-deficient $o b / o b$ mice to study whether specific ghrelin deficiency or desacyl ghrelin abundance modifies glucose tolerance on a massively obese background (63). As targeted deletion of ghrelin does not improve glucose homeostasis in their GOAT-ob/ob mouse model, they conclude that neither ghrelin nor the increased ratio of desacyl/acyl ghrelin is crucial for controlling glucose homeostasis in their model of massive obesity induced by leptin deficiency.

Thus, although the role of ghrelin on glucose metabolism is partly unknown, glucose tolerance improved when a GOAT-selective antagonist called GO-CoA-Tat was injected into wild-type mice that were fed a high-fat diet, and body weight gain inhibited (64). Metabolic diseases associated with obesity are a public health issue, and if these theories can be clinically applied, they would be highly significant. Treatment with GO-CoA-Tat is based on a peptide that requires repeated injection; therefore, at the present time, clinical application is difficult. However, GOAT is a potentially useful target for future drug development for obesity.

\subsection{Effects on the Circulatory System}

When ghrelin was administered twice daily for 3 weeks to chronic cardiac failure model rats, there were signs of an improvement in cardiac function, including decreased peripheral vascular resistance, increased cardiac output, increased left ventricular ejection fraction, suppression of the progression of left ventricular modeling, and promotion of compensatory cardiac hypertrophy in non-infarcted areas (65). In addition to these direct effects of ghrelin, there were also effects mediated by increased GH/IGF-1 caused by ghrelin. In addition, in an investigation using local administration into the anterior brachial artery in humans and GH gene-deficient pygmy rats, it became clear that ghrelin increased perfusion and decreased blood pressure in a manner independent of GH and IGF-1 $(66,67)$; we believe this was mediated by ghrelin receptor present in the blood vessels; therefore, ghrelin demonstrates vasodilatory effects.
When a single dose of ghrelin is administered intravenously to healthy individuals, the plasma $\mathrm{GH}$ concentration increases and the mean arterial pressure decreases by around $10 \mathrm{mmHg}$ (68). Furthermore, cardiac index and cardiac output increase without changes in heart rate (68). The above show that ghrelin alters hemodynamics through suppression of the sympathetic nervous system. Moreover, in patients with chronic heart failure associated with cachexia, plasma GH, and ghrelin concentrations elevated (69). As plasma ghrelin concentration shows a positive correlation with BMI, plasma TNF- $\alpha$, and plasma $\mathrm{GH}$ concentration, it is thought to play a compensatory role during a pathological condition of cachexia, where there tend to be abnormalities of energy metabolism.

\subsection{Effects on the Bone}

Ghrelin localized in osteoblast-like cells significantly increased their numbers and DNA synthesis in vitro. These proliferative effects of ghrelin were suppressed by [D-Lys ${ }^{3}$ ]-GHRP-6, an antagonist of GHS-R1a. Furthermore, ghrelin increased the expression of osteoblast differentiation markers, ALP activity, and calcium accumulation in the matrix. Thus, ghrelin directly stimulates bone formation (70). In addition, it was reported that ghrelin also regulates bone remodeling through GHS-R in osteoblasts by modulating the cAMP response element binding protein (CREB) and runt-related transcription factor 2 (Runx2) pathways in mice (71). Moreover, chronic central administration of ghrelin increases bone mass through a mechanism that is independent of body weight, suggesting that ghrelin may have a bone anabolic effect through the central nervous system (72). On the other hand, ghrelin infusion has no acute effect on markers of bone turnover in healthy controls and post-gastrectomy subjects, which are prone to osteropenia and osteomalacia, but is inversely correlated with bone resorption (73). Thus, the effects of ghrelin on bone are not necessarily consistent results between experimental animals and humans.

\section{Conclusion}

By the discovery of ghrelin, the stomach has been shown to be involved in $\mathrm{GH}$ secretion and regulation of energy metabolism, in addition to its primary digestive function. Ghrelin was the first peptide proven to promote food intake peripherally, and clarification of its mode of action is important for elucidation of the etiology and pathology of obesity and eating disorders. It is anticipated that future research will study the mechanisms of the numerous physiological functions of ghrelin at a molecular level in order to be applied to drug discovery. Following on from this, we expect ghrelin to play an important role in innovative drug development.

\section{Acknowledgements}

The authors thank M. Yamane and S. Koga (Kurume University) for their technical assistance. The study supported by Grants-in-Aid for Scientific Research from the Ministry of 
Education, Cultures, Sports, Science and Technology of Japan (22126003 to M.K.), the Grant-in-Aid for Young Scientists (B) (20790665), the Grant-in-Aid for the Strategic Research Foundation for Private Universities from MEXT, Japan (M.K.), the grant from the Ishibashi Foundation for the Promotion of Science (T.S.), and the Takeda Science Foundation (T.S.). The authors thank Crimson Interactive Pvt. Ltd. (Ulatus) www.ulatus.jp for their assistance in manuscript translation and editing.

\section{References}

[1] Bowers, C. Y., Momany, F., Reynolds, G. A., Chang, D., Hong, A., and Chang, K. (1980) Structure-Activity Relationships of a Synthetic Pentapeptide That Specifically Releases Growth Hormone in Vitro Endocrinology 106, 663-667

[2] Howard, A. D., Feighner, S. D., Cully, D. F., Arena, J. P., Liberator, P. A., Rosenblum, C. I., Hamelin, M., Hreniuk, D. L., Palyha, O. C., Anderson, J., Paress, P. S., Diaz, C., Chou, M., Liu, K. K., McKee, K. K., Pong, S. S., Chaung, L. Y., Elbrecht, A., Dashkevicz, M., Heavens, R., Rigby, M., Sirinathsinghji, D. J., Dean, D. C., Melillo, D. G., Patchett, A. A., Nargund, R., Griffin, P. R., DeMartino, J. A., Gupta, S. K., Schaeffer, J. M., Smith, R. G., and Van der Ploeg, L. H. (1996) A Receptor in Pituitary and Hypothalamus That Functions in Growth Hormone Release Science 273, 974-977

[3] Bennett, P. A., Thomas, G. B., Howard, A. D., Feighner, S. D., van der Ploeg, L. H., Smith, R. G., and Robinson, I. C. (1997) Hypothalamic Growth Hormone Secretagogue-Receptor (Ghs-R) Expression Is Regulated by Growth Hormone in the Rat Endocrinology 138, 4552-4557

[4] Guan, X. M., Yu, H., Palyha, O. C., McKee, K. K., Feighner, S. D., Sirinathsinghji, D. J., Smith, R. G., Van der Ploeg, L. H., and Howard, A. D. (1997) Distribution of Mrna Encoding the Growth Hormone Secretagogue Receptor in Brain and Peripheral Tissues Brain Res Mol Brain Res 48, 23-29

[5] Kojima, M., Hosoda, H., Date, Y., Nakazato, M., Matsuo, H., and Kangawa, K. (1999) Ghrelin Is a Growth-Hormone-Releasing Acylated Peptide from Stomach Nature 402, 656-660

[6] Smith, R. G., Van der Ploeg, L. H., Howard, A. D., Feighner, S. D., Cheng, K., Hickey, G. J., Wyvratt, M. J., Jr., Fisher, M. H., Nargund, R. P., and Patchett, A. A. (1997) Peptidomimetic Regulation of Growth Hormone Secretion Endocr Rev 18, 621-645

[7] Kojima, M., and Kangawa, K. (2005) Ghrelin: Structure and Function Physiol Rev 85, 495-522

[8] Kanamoto, N., Akamizu, T., Tagami, T., Hataya, Y., Moriyama, K., Takaya, K., Hosoda, H., Kojima, M., Kangawa, K., and Nakao, K. (2004) Genomic Structure and Characterization of the 5'-Flanking Region of the Human Ghrelin Gene Endocrinology 145, 4144-4153

[9] Tanaka, M., Hayashida, Y., Iguchi, T., Nakao, N., Nakai, N., and Nakashima, K. (2001) Organization of the Mouse Ghrelin Gene and Promoter: Occurrence of a Short Noncoding First Exon Endocrinology 142, 3697-3700

[10] Angeloni, S. V., Glynn, N., Ambrosini, G., Garant, M. J., Higley, J. D., Suomi, S., and Hansen, B. C. (2004)
Characterization of the Rhesus Monkey Ghrelin Gene and Factors Influencing Ghrelin Gene Expression and Fasting Plasma Levels Endocrinology 145, 2197-2205

[11] Tomasetto, C., Wendling, C., Rio, M. C., and Poitras, P. (2001) Identification of Cdna Encoding Motilin Related Peptide/Ghrelin Precursor from Dog Fundus Peptides 22, 2055-2059

[12] Kaiya, H., Van Der Geyten, S., Kojima, M., Hosoda, H., Kitajima, Y., Matsumoto, M., Geelissen, S., Darras, V. M., and Kangawa, K. (2002) Chicken Ghrelin: Purification, Cdna Cloning, and Biological Activity Endocrinology 143, 3454-3463

[13] Kaiya, H., Kojima, M., Hosoda, H., Koda, A., Yamamoto, K., Kitajima, Y., Matsumoto, M., Minamitake, Y., Kikuyama, S., and Kangawa, K. (2001) Bullfrog Ghrelin Is Modified by N-Octanoic Acid at Its Third Threonine Residue $J$ Biol Chem 276, 40441-40448

[14] Kaiya, H., Kojima, M., Hosoda, H., Moriyama, S., Takahashi, A., Kawauchi, H., and Kangawa, K. (2003) Peptide Purification, Complementary Deoxyribonucleic Acid (DNA) and Genomic DNA Cloning, and Functional Characterization of Ghrelin in Rainbow Trout Endocrinology 144, 5215-5226

[15] Kaiya, H., Kojima, M., Hosoda, H., Riley, L. G., Hirano, T., Grau, E. G., and Kangawa, K. (2003) Amidated Fish Ghrelin: Purification, Cdna Cloning in the Japanese Eel and Its Biological Activity $J$ Endocrinol 176, 415-423

[16] Kaiya, H., Kojima, M., Hosoda, H., Riley, L. G., Hirano, T., Grau, E. G., and Kangawa, K. (2003) Identification of Tilapia Ghrelin and Its Effects on Growth Hormone and Prolactin Release in the Tilapia, Oreochromis Mossambicus Comp Biochem Physiol B Biochem Mol Biol 135, 421-429

[17] Parhar, I. S., Sato, H., and Sakuma, Y. (2003) Ghrelin Gene in Cichlid Fish Is Modulated by Sex and Development Biochem Biophys Res Commun 305, 169-175

[18] Unniappan, S., Lin, X., Cervini, L., Rivier, J., Kaiya, H., Kangawa, K., and Peter, R. E. (2002) Goldfish Ghrelin: Molecular Characterization of the Complementary Deoxyribonucleic Acid, Partial Gene Structure and Evidence for Its Stimulatory Role in Food Intake Endocrinology 143, 4143-4146

[19] Toshinai, K., Yamaguchi, H., Sun, Y., Smith, R. G., Yamanaka, A., Sakurai, T., Date, Y., Mondal, M. S., Shimbara, T., Kawagoe, T., Murakami, N., Miyazato, M., Kangawa, K., and Nakazato, M. (2006) Des-Acyl Ghrelin Induces Food Intake by a Mechanism Independent of the Growth Hormone Secretagogue Receptor Endocrinology 147, 2306-2314

[20] Yang, J., Brown, M. S., Liang, G., Grishin, N. V., and Goldstein, J. L. (2008) Identification of the Acyltransferase That Octanoylates Ghrelin, an Appetite-Stimulating Peptide Hormone Cell 132, 387-396

[21] Ohgusu, H., Shirouzu, K., Nakamura, Y., Nakashima, Y., Ida, T., Sato, T., and Kojima, M. (2009) Ghrelin O-Acyltransferase (Goat) Has a Preference for N-Hexanoyl-Coa over N-Octanoyl-Coa as an Acyl Donor Biochem Biophys Res Commun 386, 153-158

[22] Laviano, A., Molfino, A., Rianda, S., and Rossi Fanelli, F. (2012) The growth hormone secretagogue receptor (Ghs-R) Curr Pharm Des 18, 4749-4754 
[23] Feighner, S. D., Tan, C. P., McKee, K. K., Palyha, O. C., Hreniuk, D. L., Pong, S. S., Austin, C. P., Figueroa, D., MacNeil, D., Cascieri, M. A., Nargund, R., Bakshi, R., Abramovitz, M., Stocco, R., Kargman, S., O'Neill, G., Van Der Ploeg, L. H., Evans, J., Patchett, A. A., Smith, R. G., and Howard, A. D. (1999) Receptor for Motilin Identified in the Human Gastrointestinal System Science 284, 2184-2188

[24] Inui, A. (2001) Ghrelin: An Orexigenic and Somatotrophic Signal from the Stomach Nat Rev Neurosci 2, 551-560

[25] Smith, R. G., Leonard, R., Bailey, A. R., Palyha, O., Feighner, S., Tan, C., McKee, K. K., Pong, S. S., Griffin, P., and Howard, A. (2001) Growth Hormone Secretagogue Receptor Family Members and Ligands Endocrine 14, 9-14

[26] Zhang, J. V., Ren, P. G., Avsian-Kretchmer, O., Luo, C. W., Rauch, R., Klein, C., and Hsueh, A. J. (2005) Obestatin, a Peptide Encoded by the Ghrelin Gene, Opposes Ghrelin's Effects on Food Intake Science 310, 996-999

[27] Gourcerol, G., Million, M., Adelson, D. W., Wang, Y., Wang, L., Rivier, J., St-Pierre, D. H., and Tache, Y. (2006) Lack of Interaction between Peripheral Injection of Cck and Obestatin in the Regulation of Gastric Satiety Signaling in Rodents Peptides 27, 2811-2819

[28] Holst, B., Egerod, K. L., Schild, E., Vickers, S. P., Cheetham, S., Gerlach, L. O., Storjohann, L., Stidsen, C. E., Jones, R., Beck-Sickinger, A. G., and Schwartz, T. W. (2007) Gpr39 Signaling Is Stimulated by Zinc Ions but Not by Obestatin Endocrinology 148, 13-20

[29] Yamamoto, D., Ikeshita, N., Daito, R., Herningtyas, E. H., Toda, K., Takahashi, K., Iida, K., Takahashi, Y., Kaji, H., Chihara, K., and Okimura, Y. (2007) Neither Intravenous nor Intracerebroventricular Administration of Obestatin Affects the Secretion of Gh, Prl, Tsh and Acth in Rats Regul Pept 138, $141-144$

[30] Date, Y., Kojima, M., Hosoda, H., Sawaguchi, A., Mondal, M. S., Suganuma, T., Matsukura, S., Kangawa, K., and Nakazato, M. (2000) Ghrelin, a Novel Growth Hormone-Releasing Acylated Peptide, Is Synthesized in a Distinct Endocrine Cell Type in the Gastrointestinal Tracts of Rats and Humans Endocrinology 141, 4255-4261

[31] Date, Y., Nakazato, M., Hashiguchi, S., Dezaki, K., Mondal, M. S., Hosoda, H., Kojima, M., Kangawa, K., Arima, T., Matsuo, H., Yada, T., and Matsukura, S. (2002) Ghrelin Is Present in Pancreatic Alpha-Cells of Humans and Rats and Stimulates Insulin Secretion Diabetes 51, 124-129

[32] Sato, T., Fukue, Y., Teranishi, H., Yoshida, Y., and Kojima, M. (2005) Molecular Forms of Hypothalamic Ghrelin and Its Regulation by Fasting and 2-Deoxy-D-Glucose Administration Endocrinology 146, 2510-2516

[33] Cummings, D. E., Purnell, J. Q., Frayo, R. S., Schmidova, K., Wisse, B. E., and Weigle, D. S. (2001) A Preprandial Rise in Plasma Ghrelin Levels Suggests a Role in Meal Initiation in Humans Diabetes 50, 1714-1719

[34] Tschop, M., Wawarta, R., Riepl, R. L., Friedrich, S., Bidlingmaier, M., Landgraf, R., and Folwaczny, C. (2001) Post-Prandial Decrease of Circulating Human Ghrelin Levels $J$ Endocrinol Invest 24, RC19-21

[35] Dzaja, A., Dalal, M. A., Himmerich, H., Uhr, M., Pollmacher, T., and Schuld, A. (2004) Sleep Enhances Nocturnal Plasma
Ghrelin Levels in Healthy Subjects Am J Physiol Endocrinol Metab 286, E963-967

[36] Hosoda, H., Kojima, M., Matsuo, H., and Kangawa, K. (2000) Purification and Characterization of Rat Des-Gln14-Ghrelin, a Second Endogenous Ligand for the Growth Hormone Secretagogue Receptor J Biol Chem 275, 21995-22000

[37] Dzaja, A., Dalal, M. A., Himmerich, H., Uhr, M., Pollmacher, T., and Schuld, A. (2004) Sleep Enhances Nocturnal Plasma Ghrelin Levels in Healthy Subjects Am J Physiol Endocrinol Metab 286, E963-967

[38] Yildiz, B. O., Suchard, M. A., Wong, M. L., McCann, S. M., and Licinio, J. (2004) Alterations in the Dynamics of Circulating Ghrelin, Adiponectin, and Leptin in Human Obesity Proc Natl Acad Sci U S A 101, 10434-10439

[39] Shiiya, T., Nakazato, M., Mizuta, M., Date, Y., Mondal, M. S., Tanaka, M., Nozoe, S., Hosoda, H., Kangawa, K., and Matsukura, S. (2002) Plasma Ghrelin Levels in Lean and Obese Humans and the Effect of Glucose on Ghrelin Secretion J Clin Endocrinol Metab 87, 240-244

[40] Arvat, E., Di Vito, L., Broglio, F., Papotti, M., Muccioli, G., Dieguez, C., Casanueva, F. F., Deghenghi, R., Camanni, F., and Ghigo, E. (2000) Preliminary Evidence That Ghrelin, the Natural Gh Secretagogue (Ghs)-Receptor Ligand, Strongly Stimulates Gh Secretion in Humans J Endocrinol Invest 23, 493-495

[41] Arvat, E., Maccario, M., Di Vito, L., Broglio, F., Benso, A., Gottero, C., Papotti, M., Muccioli, G., Dieguez, C., Casanueva, F. F., Deghenghi, R., Camanni, F., and Ghigo, E. (2001) Endocrine Activities of Ghrelin, a Natural Growth Hormone Secretagogue (Ghs), in Humans: Comparison and Interactions with Hexarelin, a Nonnatural Peptidyl Ghs, and Gh-Releasing Hormone J Clin Endocrinol Metab 86, 1169-1174

[42] Date, Y., Murakami, N., Kojima, M., Kuroiwa, T., Matsukura, S., Kangawa, K., and Nakazato, M. (2000) Central Effects of a Novel Acylated Peptide, Ghrelin, on Growth Hormone Release in Rats Biochem Biophys Res Commun 275, 477-480

[43] Peino, R., Baldelli, R., Rodriguez-Garcia, J., Rodriguez-Segade, S., Kojima, M., Kangawa, K., Arvat, E., Ghigo, E., Dieguez, C., and Casanueva, F. F. (2000) Ghrelin-Induced Growth Hormone Secretion in Humans Eur J Endocrinol 143, R11-14

[44] Takaya, K., Ariyasu, H., Kanamoto, N., Iwakura, H., Yoshimoto, A., Harada, M., Mori, K., Komatsu, Y., Usui, T., Shimatsu, A., Ogawa, Y., Hosoda, K., Akamizu, T., Kojima, M., Kangawa, K., and Nakao, K. (2000) Ghrelin Strongly Stimulates Growth Hormone Release in Humans $J$ Clin Endocrinol Metab 85, 4908-4911

[45] Hataya, Y., Akamizu, T., Takaya, K., Kanamoto, N., Ariyasu, H., Saijo, M., Moriyama, K., Shimatsu, A., Kojima, M., Kangawa, K., and Nakao, K. (2001) A Low Dose of Ghrelin Stimulates Growth Hormone (Gh) Release Synergistically with Gh-Releasing Hormone in Humans J Clin Endocrinol Metab 86, 4552

[46] Barlier, A., Zamora A. J., Grino, M., Gunz, G., Pellegrini-Bouiller, I., Morange-Ramos, I., Figarella-Branger, D., Dufour, H., Jaquet, P., and Enjalbert, A. (1999) Expression of Functional Growth Hormone Secretagogue Receptors in Human Pituitary Adenomas: Polymerase Chain Reaction, Triple in-situ Hybridization and Cell Culture Studies $J$ Neuroendocrinol 11, 491-502 
[47] Gracia, A., Alvarez, C. V. Smith, R. G., Dieguez, C. (2001) Regulation of Pit-1 Expression by Ghrelin and GHRP-6 Through the GH Secretagogue Receptor Mol Endocrinol 15, $1484-1495$

[48] Nakazato, M., Murakami, N., Date, Y., Kojima, M., Matsuo, H., Kangawa, K., and Matsukura, S. (2001) A Role for Ghrelin in the Central Regulation of Feeding Nature 409, 194-198

[49] Ruter, J., Kobelt, P., Tebbe, J. J., Avsar, Y., Veh, R., Wang, L., Klapp, B. F., Wiedenmann, B., Tache, Y., and Monnikes, H. (2003) Intraperitoneal Injection of Ghrelin Induces Fos Expression in the Paraventricular Nucleus of the Hypothalamus in Rats Brain Res 991, 26-33

[50] Tschop, M., Smiley, D. L., and Heiman, M. L. (2000) Ghrelin Induces Adiposity in Rodents Nature 407, 908-913

[51] Wang, L., Saint-Pierre, D. H., and Tache, Y. (2002) Peripheral Ghrelin Selectively Increases Fos Expression in Neuropeptide Y - Synthesizing Neurons in Mouse Hypothalamic Arcuate Nucleus Neurosci Lett 325, 47-51

[52] Wren, A. M., Seal, L. J., Cohen, M. A., Brynes, A. E., Frost, G. S., Murphy, K. G., Dhillo, W. S., Ghatei, M. A., and Bloom, S. R. (2001) Ghrelin Enhances Appetite and Increases Food Intake in Humans J Clin Endocrinol Metab 86, 5992

[53] Date, Y., Murakami, N., Toshinai, K., Matsukura, S., Niijima, A., Matsuo, H., Kangawa, K., and Nakazato, M. (2002) The Role of the Gastric Afferent Vagal Nerve in Ghrelin-Induced Feeding and Growth Hormone Secretion in Rats Gastroenterology 123, 1120-1128

[54] Cowley, M. A., Smith, R. G., Diano, S., Tschop, M., Pronchuk, N., Grove, K. L., Strasburger, C. J., Bidlingmaier, M., Esterman, M., Heiman, M. L., Garcia-Segura, L. M., Nillni, E. A., Mendez, P., Low, M. J., Sotonyi, P., Friedman, J. M., Liu, H., Pinto, S., Colmers, W. F., Cone, R. D., and Horvath, T. L. (2003) The Distribution and Mechanism of Action of Ghrelin in the Cns Demonstrates a Novel Hypothalamic Circuit Regulating Energy Homeostasis Neuron 37, 649-661

[55] Qi, Y., Inoue, K., Fu, M., Inui, A., and Herzog, H. (2015) Chronic Overproduction of Ghrelin in the Hypothalamus Leads to Temoporal Increase in Food Intake and Body Weight Neuropeptides 15 , in press

[56] Cummings, D. E., Clement, K., Purnell, J. Q., Vaisse, C., Foster, K. E., Frayo, R. S., Schwarts, M. W., Basdevant, A., and Weigle, D. S. (2002) Elevated Plasma Ghrelin Levels in Prader Willi Syndrome Nat Med 8, 643-644.

[57] De Waele, K., Ishkanian, S. L., Bogarin, R., Miranda, C. A., Ghatei, M. A., Bloom, S. R., Pacaud, D., and Chanoine, J. P. (2008) Long-acting Octreotide Treatment Causes a Sustained Decrease in Ghrelin Concentrations But Does Not Affect Weight, Behavior and Appetite in Subjects with Prader-Willi Syndrome Eur J Endocrinol 159:381-388

[58] Steculorum, S. M., Collden, G., Coupe, B., Croizier, S., Lockie, S., Andrews, Z. B., Jarosch, F., Klussmann, S., and Bouret, S. G. Neonatal Ghrelin Programs Development of Hypothalamic Feeding Circuits J Clin Invest 125, 846-858

[59] Adeghate, E., and Ponery, A. S. (2002) Ghrelin Stimulates Insulin Secretion from the Pancreas of Normal and Diabetic Rats $J$ Neuroendocrinol 14, 555-560

[60] Lee, H. M., Wang, G., Englander, E. W., Kojima, M., and
Greeley, G. H., Jr. (2002) Ghrelin, a New Gastrointestinal Endocrine Peptide That Stimulates Insulin Secretion: Enteric Distribution, Ontogeny, Influence of Endocrine, and Dietary Manipulations Endocrinology 143, 185-190

[61] Reimer, M. K., Pacini, G., and Ahren, B. (2003) Dose-Dependent Inhibition by Ghrelin of Insulin Secretion in the Mouse Endocrinology 144, 916-921

[62] Dezaki, K., Sone, H., Koizumi, M., Nakata, M., Kakei, M., Nagai, H., Hosoda, H., Kangawa, K., and Yada, T. (2006) Blockade of Pancreatic Islet-Derived Ghrelin Enhances Insulin Secretion to Prevent High-Fat Diet-Induced Glucose Intolerance Diabetes 55, 3486-3493

[63] Kirchener, H., Heppner, K. M., Holland, J., Kabra, D., Tschop, M. H., Pfluger, P. T. (2013) Ablation of Ghrelin $O$-acyltransferase Does Not Improve Glucose Intolerance or Body Adiposity in Mice on a Leptin-deficient ob/ob/ Background PLoS One 8, e61822

[64] Barnett, B. P., Hwang, Y., Taylor, M. S., Kirchner, H., Pfluger, P. T., Bernard, V., Lin, Y. Y., Bowers, E. M., Mukherjee, C., Song, W. J., Longo, P. A., Leahy, D. J., Hussain, M. A., Tschop, M. H., Boeke, J. D., and Cole, P. A. Glucose and Weight Control in Mice with a Designed Ghrelin O-Acyltransferase Inhibitor Science 330, 1689-1692

[65] Nagaya, N., Moriya, J., Yasumura, Y., Uematsu, M., Ono, F., Shimizu, W., Ueno, K., Kitakaze, M., Miyatake, K., and Kangawa, K. (2004) Effects of Ghrelin Administration on Left Ventricular Function, Exercise Capacity, and Muscle Wasting in Patients with Chronic Heart Failure Circulation 110, 3674-3679

[66] Okumura, H., Nagaya, N., Enomoto, M., Nakagawa, E., Oya, H., and Kangawa, K. (2002) Vasodilatory Effect of Ghrelin, an Endogenous Peptide from the Stomach $J$ Cardiovasc Pharmacol 39, 779-783

[67] Shimizu, Y., Nagaya, N., Teranishi, Y., Imazu, M., Yamamoto, H., Shokawa, T., Kangawa, K., Kohno, N., and Yoshimizu, M. (2003) Ghrelin Improves Endothelial Dysfunction Through Growth Hormone-independent Mechanisms in Rats Biochem Biophys Res Commun 310, 830-835

[68] Nagaya, N., Uematsu, M., Kojima, M., Date, Y., Nakazato, M., Okumura, H., Hosoda, H., Shimizu, W., Yamagishi, M., Oya, H., Koh, H., Yutani, C., and Kangawa, K. (2001) Elevated Circulating Level of Ghrelin in Cachexia Associated with Chronic Heart Failre Circulation 104, 2034-2046

[69] Nagaya, N., and Kangawa, K. (2003) Ghrelin Improves Left Ventricular Dysfunction and Cardiac Cachexia in Heart Failure Curr Opin Pharmacol 3, 146-151

[70] Fukushima, N., Hanada, R., Teranishi, H., Fukue, Y., Tachibana, T. Ishikawa, H., Takeda, S., Takeuchi, Y., Fukumoto, S., Kanagawa, K., Nagata, K., and Kojima, M. (2004) Ghrelin Directly Regulates Bone Formation J Bone Miner Res 20, 790-798

[71] Ma, C., Fukuda, T., Ochi, H., Sunamura, S., Xu, C., Xu, R., Okawa, A., and Takeda, S. (2015) Genetic Determination of the Cellular Basis of the Ghrelin-dependent Bone Remodeling Mol Metab 4, 175-85

[72] Choi, H. J., Ki, K. H., Yang, J. Y., Jang, B. Y., Song, J. A., Baek, W, Y., Kim, J. H., An, J. H., Kim, S. W., Kim, S. Y., Kim, J. E., and Shin, C. S. (2013) Chronic Central Administration o Ghrelin Increases Bone Mass Through a Mechanism Independent of Appetite Regulation Plos One 8, e65505 
[73] Huda, M. S., Durham, B. H., Wong, S. P., Dovey, T. M., McCulloch, P., Kerrigan, D., Pinkney, J. H., Fraser, W. D., and Wilding, J. P. (2007) Lack of an Acute Effect of Ghrelin on
Markers of Bone Turnover in Healthy Controls and Post-gastrectomy Subjects Bone 41, 406-413. 